УДК 631.5:633.2:631.559:631:559

(C) 2013

Кулик М. І., кандидат сільськогосподарських наук

Полтавська державна аграрна академія

\title{
ВПЛИВ УМОВ ВИРОЩУВАННЯ НА ВРОЖАЙНІСТЬ ФІТОМАСИ CВITЧГРАСУ (PANICUM VIRGATUM L.) ДРУГОГО РОКУ ВЕГЕТАЦÏ̈
}

\section{Рецензент - кандидат сільськогосподарських наук М. М. Маренич}

\begin{abstract}
Наведено особливості формування врожайності фітомаси світчграсу - проса лозовидного за вирощування його на деградованих трунтах із метою отримання сировини для виробництва біопалива. Подано фенологічні спостереження - тривалість міжфазних періодів під час вететаиії культури другого року життя. Встановлено кількісні показники вететативної частини рослин, подано їх взаємозв'язок та влив на формування врожайності культури. Визначена продуктивність фітомаси світчграсу досліджуваних сортів за різної иирина міжрядь.
\end{abstract}

Ключові слова: сорти, міжряддя, кількісні показники, світчграс, фітомаса, врожайність.

Постановка проблеми. Широке залучення нетрадиційних і поновлюваних джерел в енергетичний баланс аграрної галузі - перспективний напрям, що забезпечує зменшення енергетичного дефіциту й охорону навколишнього середовища. Крім того скорочення споживання природного газу та розвиток енергозбереження - найбільш актуальні задачі, що стоять наразі перед Україною [1].

У зв'язку 3 тим, що світчграс (просо лозовидне) Panicum virgatum L. $є$ однією із фітоенергетичних культур, вегетативна маса якої використовується для виробництва твердого палива, рослини ростуть на різних типах грунтів, а на території України знаходиться декілька мільйонів гектарів таких земель, то вивчення можливостей вирощування культури на цих землях $є$ актуальним [8]. Не менш важливим є й те, що за вирощування світчграсу на зазначених землях зменшуються ерозійні процеси і покращується екологія довкілля $[6,10,12]$.

Аналіз основних досліджень і публікацій, у яких започатковано розв'язання проблеми. 3-поміж інтродукованих «енергетичних культур» світчграс - просо лозовидне (Panicum virgatum L.) добре акліматизований до умов вирощування, формує високу продуктивність із відповідною якістю фітомаси, що використовується як сировина для виробництва паливних гранул $[2,4,9]$.

Основними шляхами використання світчграсу $\epsilon$ виробництво електроенергії через газифікацію, комбіноване спалювання на вугільних заводах, виробництво етанолу для пального та виробництва паливних гранул $[14,15]$.

В агротехніці вирощування світчграсу важливим фактором, що визначає врожайність культури, є ширина міжрядь. Вузькі міжряддя прискорюють закриття грунту навесні й збільшують кількість світла, що поглинається рослиною протягом вегетаційного періоду, і це певним чином впливає на врожайність культури та зменшує необхідність боротьби із забур'яненістю, адже за меншої площі живлення рослини швидше розростатимуться у міжрядді. Проте водночас виникає проблема самопроріджування, що знижує загальний об'єм біомаси 3 площі; крім того у густого травостою більша можливість ураження хворобами й вилягання. Було проведено декілька досліджень щодо ширини міжрядь на посівах світчграсу. Так, W. R. Ocumpaugh та інші вчені [16], порівнявши результати досліджень за вирощування світчграсу за ширини міжрядь 15, 30 і 50 см довели, що за посушливих умов посіви 3 широким міжряддям мали вищу урожайність.

За широкого міжряддя досліджувані сорти світчграсу, як встановив D. I. Bransby зі співавторами [11], дають більшу урожайність, порівняно 3 вузьким. Підвищення урожаю особливо було помітним через декілька років.

Згідно з дослідженнями, проведеними в умовах України, встановлено [5], що на висоту рослин світчграсу першого року вегетації більший вплив мають сортові особливості за ширини міжрядь 30 см, а при 45 см ця різниця зникає, що може свідчити про те, що зі збільшенням площі живлення рослин знижується їх конкуренція за мінеральні поживні речовини й спостерігається вирівнювання за висотою у досліджуваних сортів світчграсу. Дана тенденція зберігалась і стосовно густоти рослин на одиниці площі, але для більшої кількості сортів (Форесбург, Канлоу і Кейв-ін-рок). Це вказує на те, що даний показник (густота рослин) може бути більш надійним параметром, аніж висота в оцінці продуктивнос- 
ті сортів світчграсу для виробництва біомаси.

Інші вчені [8] визначили: сорти Кейв-ін-рок та Санбурст за весняного строку сівби на другий рік вегетації формують врожайність, відповідно, 11,5 та 8,7 т/га сухої біомаси, а літній строк сівби суттєво зменшує продуктивність культури. Ними встановлено, що оптимальні умови для світчграсу можна створити певними агротехнічними заходами та засобами, підбираючи сорти з урахуванням агробіологічних особливостей регіону й погодних умов року.

Отже, недостатньо вивчені елементи технології вирощування світчграсу в умовах України викликають необхідність дослідити це питання й встановити особливості формування продуктивності фітомаси світчграсу за вирощування на малопродуктивних грунтах.

Мета досліджень: встановити вплив елементів структури врожаю на продуктивність фітомаси сортів світчграсу за їх вирощування на деградованих грунтах із різною шириною міжрядь.

Відповідно до поставленої мети досліджень передбачалось вирішення таких завдань:

- провести фенологічні спостереження і визначити тривалість міжфазних періодів росту i розвитку рослин світчграсу в розрізі сортів;

- визначити елементи структури врожаю сортів світчграсу залежно від ширини міжрядь;

- визначити врожайність фітомаси сортів (у перерахунку на суху речовину) за вирощування рослин із міжряддям 30 і 45 сантиметрів;

- встановити кореляційні взаємозв'язки між елементами структури врожаю та їх вплив на врожайність сухої фітомаси світчграсу.

Методика проведення досліджень. У рамках міжнародного наукового проекту «Pellets for power» та згідно з роботою міжнародного технопарку «Енергія природи» у центральній частині Лісостепу України (Полтавський район), починаючи з 2011 року, було закладено експеримент, що включав дослідження п'яти сортів світчграсу. В даному повідомленні вміщені результати досліджень по трьох сортах: Кейв-ін-рок (скорочено - КIP), Картадж і Форесбург. Схема експерименту містила варіанти вирощування рослин iз міжряддям 30 і 45 см на деградованих грунтах, що мали наступні агрохімічні показники: вміст гумусу - 2,07 \%; азоту - 44,8; фосфору - 65,0 i калію 113,0 мг на 1 кг грунту.

Агротехніка в дослідах поєднувала: дискування поля та культивації (осінні та весняну), сівбу й коткування грунту, прополювання міжрядь у міру забур'яненості.

Методика закладання i проведення експери- менту - загальноприйнята, за Б. А. Доспєховим [3]. Розміщення варіантів у дослідах рендомізоване; повторність - чотириразова. Площа облікової ділянки $-10 \mathrm{~m}^{2}$.

Фенологічні спостереження під час росту й розвитку рослин здійснювали за «Методикою державного сортовипробування сільськогосподарських культур» [7] та згідно 3 класифікацією фаз розвитку багаторічних трав [13]. Облік кількісних показників світчграсу (висоту рослин, кількість листків та міжвузлів на одній рослині, а також кількість рослин на $1 \mathrm{~m}^{2}$ ) проводили на час закінчення вегетації рослин.

Врожайність визначали шляхом скошування рослин, зважуванням та перерахунку на суху вагу після визначення відсотка вологи. Отримані результати досліджень, що апробовані в досліді, обробляли за сучасними методами статистики iз застосуванням комп'ютерних програм Excel та Statistaca 6.0.

Результати досліджень. За середньодобовою температурою в період вегетації світчграсу (травень - жовтень) виокремилися останні два роки, що характеризувалися підвищеним температурним режимом за одночасного зниження кількості опадів, що вказує на посушливі умови вегетації культури у 2011 і 2012 роках.

Характеризуючи грунтові умови місця проведення досліджень можна стверджувати, що вміст у них гумусу та азоту низький, вміст фосфору середній, а вміст калію - підвищений.

Згідно 3 проведеними спостереженнями встановлено, що тривалість міжфазних періодів у досліджуваних сортів світчграсу: Картадж, Форесбург, КІР від часу відновлення вегетації (ЧВВ) до кущіння тривав 31 добу, ЧВВ - вихід у трубку - 60 діб. Надалі терміни проходження наступних періодів різнилися за сортами: період від виходу в трубку до викидання волоті у сорту Картадж тривав 8 діб, у сорту Форесбург - 11, а у сорту КІР - 9 діб; від викидання волоті до цвітіння у сортів КIP і Картадж період тривав, відповідно, за сортами 33 і 36 діб, у сорту Форесбург - 24 доби. Термін від цвітіння до дозрівання насіння (час закінчення вегетації) у сортів Картадж і КІР був найдовшим, відповідно, 77 i 72 доби, у сорту Форесбург - 67 діб (рис. 1).

Вегетаційний період за сортами Картадж, КIP і Форесбург становив 181, 174 і 162 доби відповідно.

За визначення елементів структури врожаю встановлено їх значне варіювання по сортах залежно від площі живлення рослин (див. табл.). 


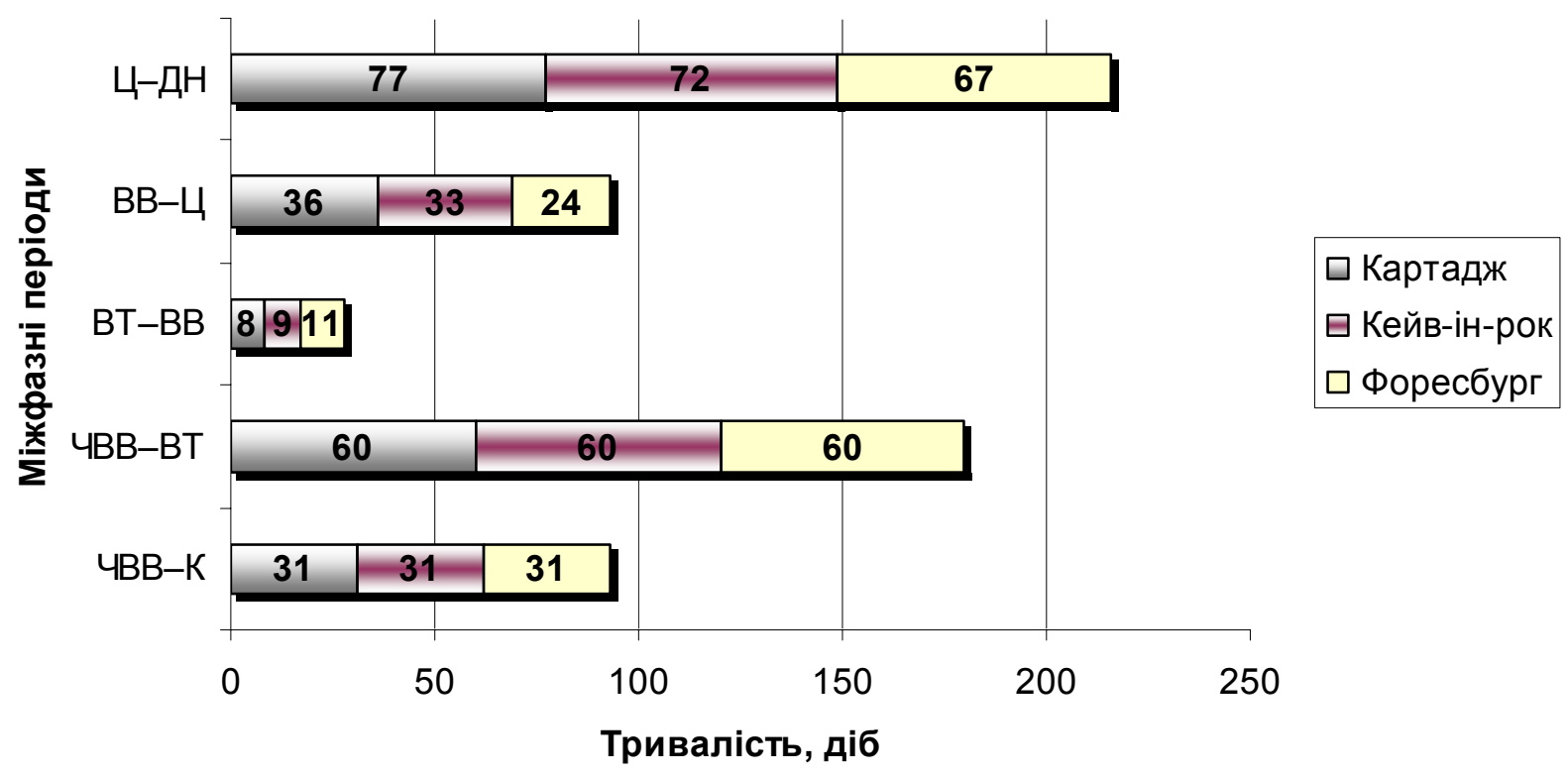

Рис. 1. Тривалість міжфазних періодів досліджуваних сортів світчграсу другого року вететаціï, 2012 p.

Примітка: ЧВВ - час відновлення вегетації, ВТ - вихід у трубку, ВВ - викидання волоті, Ц - цвітіння, ДН - дозрівання насіння

Елементи структури врожаю світчграсу другого року вегетації, 2012 p.

\begin{tabular}{|c|c|c|c|c|}
\hline \multicolumn{2}{|c|}{ Варіанти } & $\begin{array}{c}\text { Висота рослин, } \\
\text { см }\end{array}$ & $\begin{array}{c}\text { Кількість міжвуз- } \\
\text { лів на рослині, шт. }\end{array}$ & $\begin{array}{c}\text { Кількість листків } \\
\text { на рослині, см }\end{array}$ \\
\hline \multirow{2}{*}{ сорти } & міжряддя, см & 98,3 & 3,9 & 4,3 \\
\cline { 2 - 5 } Кейін-рок & 30 & 92,8 & 3,4 & 5,6 \\
\hline \multirow{2}{*}{ Картадж } & 45 & 84,2 & 3,4 & 4,2 \\
\cline { 2 - 5 } & 30 & 80,5 & 2,2 & 3,9 \\
\hline \multirow{2}{*}{ Форесбург } & 45 & 88,5 & 2,6 & 4,1 \\
\hline \multicolumn{2}{|c|}{ HIP $_{05}$ (сорти) } & 70,5 & 2,0 & 4,5 \\
\hline \multicolumn{2}{|c|}{ HIP $_{05}$ (міжряддя) } & 4,21 & 1,07 & 0,14 \\
\hline
\end{tabular}

За вирощування світчграсу на деградованих грунтах на час закінчення вегетації рослин отримали найбільшу висоту й кількість міжвузлів на стеблі у сорту КІР при міжрядді 30 см, суттєво менше у сортів Картадж і Форесбург. Обернена ситуація спостерігалася за кількістю листків на рослині - за ширини міжряддя 45 см їх було більше в усіх сортів. Кількість стебел на 1 м $^{2}$ була найбільшою за ширини міжряддя 45 см у сортів Форестбург і КІР, відповідно, 450 і 360 шт./м², у сорту Картадж - 290 шт./M².

За проведення досліджень на рослинах світч грасу другого року вегетації було визначено врожайність їх фітомаси у перерахунку на суху речовину (рис. 2).

3-поміж досліджуваних сортів світчграсу другого року вегетації найбільшу врожайність фор- мував сорт Форесбург - 6,22 т/га за ширини міжрядь 45 см, сорт Кейв-ін-рок - також за міжряддя 45 см (5,60 т/га), а Картадж при цій же площі живлення - 5,23 т/га.

За встановлення кореляції визначено зв'язки між елементами структури врожаю та врожайністю фітомаси світчграсу в розрізі досліджуваних сортів (рис. 3-5).

На рівень продуктивності фітомаси світчграсу сорту КІР другого року вегетації (як при міжрядді $30 \mathrm{~cm}$, так і 45 см) визначальним є кількість стебел і листків на рослині - коефіцієнт кореляції $з$ цими показниками високий. Висота рослин в більшій мірі має вплив на врожайність за вирощування з меншою площею живлення рослин.

За вирощування світчграсу сорту Картадж при міжрядді $45 \mathrm{~cm}$, порівняно із $30 \mathrm{~cm}$, збільшується 
щільність зв'язку між висотою рослин і врожайністю фітомаси культури, тобто, визначальний вплив на формування врожайності має висота рослин.

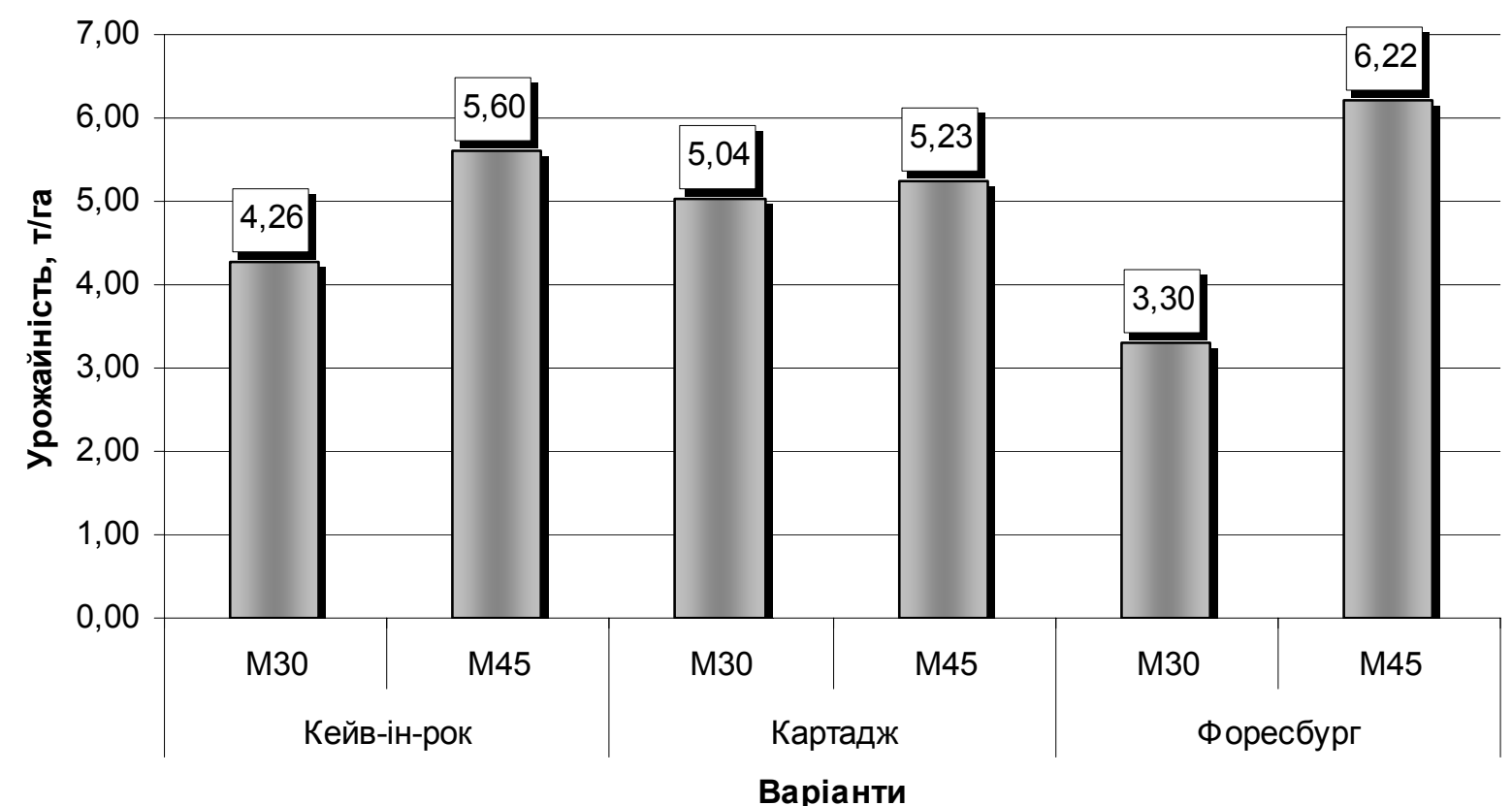

HIP 05 (сорти) 0,32 т/га, HIP 05 (міжряддя) 0,17 т/га

Рис. 2. Урожайність (суха маса рослин) світчграсу другого року вететації, (m/2a), 2012 р. Примітка: М30 - міжряддя 30 см, М45 - міжряддя 45 см

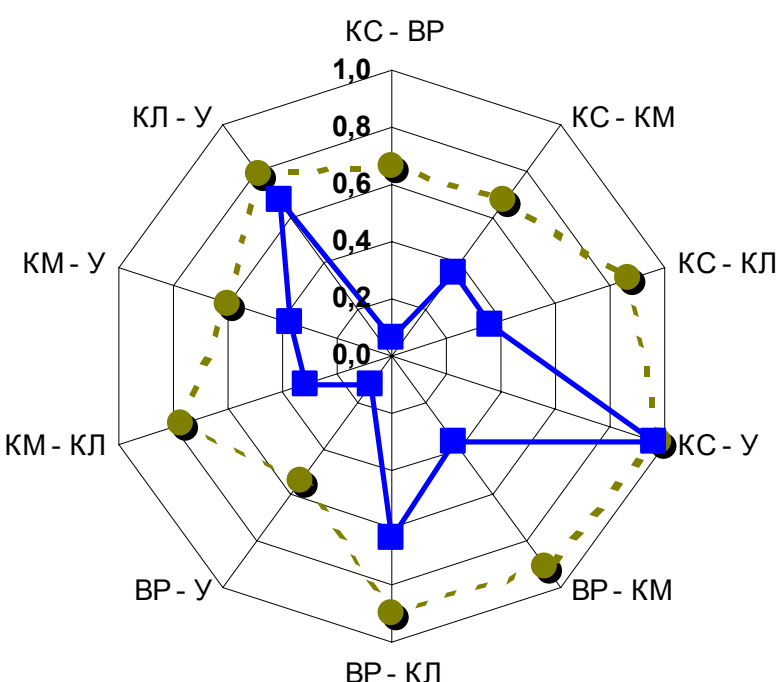

ВР - КЛ

- -๑- - Міжряддя 30 см —-Міжряддя 45 см

Рис. 3. Кореляційна плеяда (коефіцієнти кореляції між елементами структури врожаю та врожайністю сухой фітомаси світчграсу другого року вететаціï), copm KIP, 2012 p.

Примітка: КС - кількість стебел, КМ - кількість міжвузлів, КЛ - кількість листків, ВР - висота рослин, У - урожайність сухої фітомаси

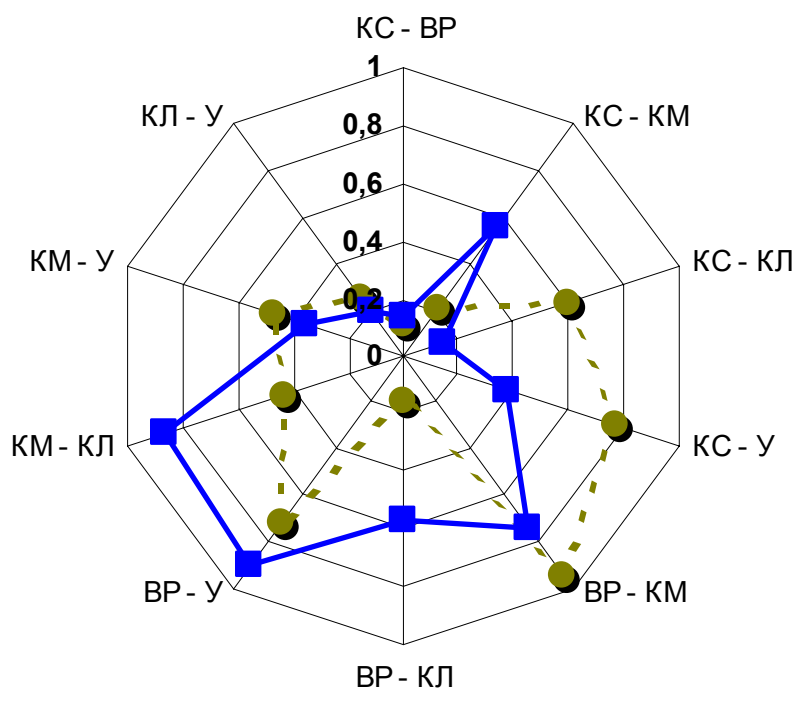

- -๑- - Міжряддя 30 см — Міжряддя 45 см

Рис. 4. Кореляційна плеяда (коефіцієнти кореляції між елементами структури врожаю та врожайністю сухої фітомаси світчграсу другого року вегетаціï), сорт Картаджс, 2012 p.

Примітка: КС - кількість стебел, КМ - кількість міжвузлів, КЛ - кількість листків, ВР - висота рослин, У - урожайність сухої фітомаси 


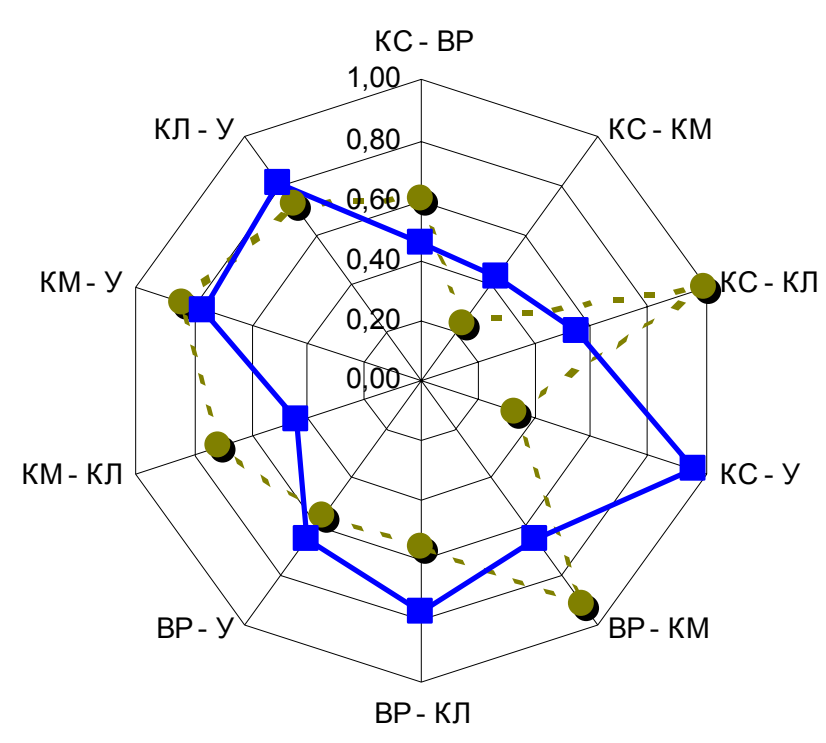

-๑- - Міжряддя 30 см —— Міжряддя 45 см

Рис. 5. Кореляційна плеяда (коефіцієнти кореляції міжс елементами структури врожсаю та врожайністю сухої фітомаси світчграсу другого року вететації), сорт Форесбург, 2012 р.

Примітка: КС - кількість стебел, КМ - кількість міжвузлів, КЛ - кількість листків, ВР - вИсота рослин, У - урожайність сухої фітомаси.

Для світчграсу сорту Форесбург другого року вегетації при міжрядді 45 см встановлені щільні кореляційні зв'язки між кількістю стебел на рослині, кількістю листків та врожайністю фітомаси, - ці показники в більшій мірі мають вплив на продуктивність культури за вирощування 3 більшою площею живлення рослин.

Висновки: 1. Вирощування світчграсу - проса лозовидного - на деградованих грунтах із метою отримання сировини для виробництва біопалива

\section{БІБЛІОГРАФІЯ}

1. Використання біомаси на енергетичні потреби / За ред. докт. техн. наук В. І. Кравчука. - Дослідницьке: УкрНДІПВТ ім. Л. Погорілого, 2009. - 72 с.

2. Гументик М. Я. Перспективи вирощування багаторічних злакових культур для виробництва біопалива / М. Я. Гументик // Цукрові буряки. 2010. - №4. - C. 21-22.

3. Доспехов Б. А. Методика полевого опыта / Борис Александрович Доспехов. - М. : Колос, 1985. - 336 с. 4. Кулик М. І. Ботаніко-біологічні особливості проса лозовидного (Panicum virgatum L.) / M. I. Кулик M. I., H. W. Elbersen, П. А. Крайсвітній [та ін.] // Матеріали Міжнародної науковопрактичної конференція «Біоенергетика: виро-
$€$ доцільним і нагальним питанням сьогодення.

2. За тривалістю вегетаційного періоду, в умовах центральної частини Лісостепу, сорт Форесбург відносимо до раннього, КІР - середній та Картадж - пізній. Це залежить від погодних умов вирощування, походження сорту, а також від його генетичної природи.

3. Кількість стебел на $1 \mathrm{~m}^{2}$, порівняно 3 міжряддям $30 \mathrm{cm,} \mathrm{була} \mathrm{найбільшою} \mathrm{при} \mathrm{міжрядді}$ 45 см у сортів другого року вегетації Форесбург і КІР, відповідно, 450 і 360 шт./м², у сорту Картадж - 290 шт./м².

4. Елементи структури врожаю мають суттєвий вплив на продуктивність сухої фітомаси світчграсу другого року життя: зі збільшенням кількості стебел на одиницю площі й кількості листків на них підвищується врожайність у сорту КІР за вирощування на міжрядді 30 і 45 сантиметрів. У сорту Форесбург дані показники впливають на продуктивність лише на міжрядді 45 сантиметрів. У сорту Картадж визначальним у формуванні врожайності $є$ висота рослин за міжряддя 45 сантиметрів.

5. У сортів світчграсу другого року вегетації найбільшу врожайність формував сорт Форесбург - 6,22 т/га при ширині міжрядь 45 см, сорт Кейв-ін-рок - також за міжряддя 45 см був високопродуктивним (5,60 т/га), а Картадж при цій же площі живлення - 5,23 т/га.

Суттєво меншу врожайність зафіксовано за вирощування даних сортів за міжряддя 30 сантиметрів.

Враховуючи, що просо лозовидне (світчграс) $є$ новою, перспективною фітоенергетичною культурою для виробництва твердого біопалива, дослідження в даному напрямі необхідно розширити й продовжити.

щування енергетичних культур, виробництво та використання біопалива», Київ, Інститут біоенергетичних культур і цукрових буряків. - 2011. C. 25-27.

5. Кулик M. I. Вплив умов вирощування на кількісні показники рослин світчграсу (Panicum virgatum L.) першого року вегетації / M. I. Кулик // Вісник Полтавської державної аграрної академії. - Полтава, 2012. - №3. - С. 62-67.

6. Кулик М. I. Раціональне використання деградованих земель для вирощування енергетичних культур і виробництва біопалива / М. І. Кулик, О. В. Рій, П. А Крайсвітній // Енергозбереження. Київ, 2012. - Вип. №4. - С. 12-13. 
7. Методика Государственного сортоиспытания сельскохозяйственных культур: Фенологические наблюдения за растениями зерновых, крупяных и зернобобовых культур / Под ред. М. А. Федина. - М. : Агропромиздат, 1988. - $121 \mathrm{c}$.

8. Мороз $O . B$. Світчграс як нова фітоенергетична культура / О. В. Мороз, В. М. Смірних, В. М. Курило [та ін.] // Цукрові буряки. - К., 2011. - Вип. №3 (81). - С. 12-14.

9. Писаренко П. В. Рослини: джерело енертії / П. В. Писаренко, П. А. Крайсвітній, М. І. Кулик [та ін.] // Енергозбереження. - К., 2010. - Вип. №11. - C. 10-11.

10. Рӧ̈к M. Ефективність вирощування високопродуктивних енергетичних культур / М. Роїк, В. Курило, М. Гументик [та ін.] // Вісник Львівського національного аграрного університету. Львів, 2011. - №15(2). - Режим доступу: http://www.nbuv.gov.ua/portal/Chem_Biol/Vldau/ Agr/2011_15_2/files.

11. Bransby D. I., Walker R. H. and Miller M. S. Development of optimal establishment and cultural practices for switchgrass as an energy crop. Five year summary report. Oak Ridge National Laboratory, Oak Ridge, TN, 1997.

12. Knight B. Global growhf/B. Kniglt, A. Westwood // The world biomass market: Renewable energy world. 2005. - Vol. 8. - №1. - P. 118-128.

13. Metcalfe D. S. and C. J. Nelson. The botany of grasses and legumes, In: M. E. Heath et al. (eds.), Forages: The science of grassland agriculture. Iowa State Univ. Press, Ames, IA., 1985. - P. 52-63.

14. Samson R. A. and J. A. Omielan. Switchgrass: A potential biomass energy crop for ethanol production Thirteenth North American Prairie Conference. Windsor, Ontario. - 1992. - P. 253-258.

15. Turhollow A. F. Screening herbaceous lignocellulosic energy crops in temperate regions of the USA. Bioresource Technology. - 1991. - №36. P. 247-252.

16. Ocumpaugh W. R., Sanderson M. A., Hussey M. A., Read J. C., Tischler C. R. and Reed R. L. Evaluation of switchgrass cultivars and cultural methods for biomass production in the southcentral U.S. Final report. Oak Ridge National Laboratory. - 1997. 